\title{
The Function and Realization of Positive Psychology in Ideological and Political Education in Colleges and Universities
}

\author{
Ying Xu \\ School of Marxism, Wuhan Textile University, Wuhan 430073, China
}

Keywords: ideological and political education; colleges and universities; positive psychology; values

\begin{abstract}
As an important education base for the cultivation of high-quality talents, colleges and universities continue to deepen the reform of higher education, and put forward higher requirements for ideological and political education in colleges and universities in the new era. Ideological and political education is an important part of the teaching and management of colleges and universities, which is directly related to students' moral qualities and values. However, due to various objective factors, the original functions of the current ideological and political education in colleges and universities have not been fully realized, and the limitations are relatively large. Therefore, in order to improve this problem, positive psychology will be integrated into ideological and political education in colleges and universities, which will help to make up for the shortcomings and deficiencies of traditional work, help students establish correct values, and improve moral quality, which will provide students with follow-up learning and development. This paper analyzes the application of positive psychology in ideological and political education in colleges and universities, and seeks reasonable ways to achieve it, in order to improve the effectiveness of ideological and political education in colleges and universities.
\end{abstract}

\section{Overview of Positive Psychology}

Positive psychology refers to the active psychological guidance to help people form positive psychological qualities and promote the healthy development of people's physical and mental health. Applying positive psychology to ideological and political education in colleges and universities can effectively improve the defects and deficiencies of the traditional education model and improve the effectiveness of education. Under the guidance of positive psychology, it helps students gain deep emotional experience, tap the potential and value of college students, and create a good education environment, which plays an important role in the development of students' quality and ability.

In the research and development of psychology, more attention is paid to the negative aspect of psychology. Negative psychology has received extensive attention and attention from all walks of life. 
It is precisely this kind of research trend that applies psychology to psychological defect correction and pathological psychotherapy, overemphasizing the development of negative psychology, which greatly restricts the continuous development of the field of psychology. As far as positive psychology is concerned, it can effectively compensate for the defects and deficiencies of the traditional psychology field in terms of positive psychological aspects, and it is reluctant to give up drastic inversion in society. Through the integration of positive forces in psychology, the research results have been continuously increased, the original thinking mode has been broken, and new vitality has been injected into the development of psychology in the new period [1]. From the perspective of positive psychology, it is a kind of psychological theory that guides students' self-development, self-development and harmonious development. Focusing on the excavation of students' strengths and potentials, students are encouraged to continuously improve and improve themselves, develop positive qualities, and lay a solid foundation and guarantee for individual follow-up development. This also plays an important role in promoting a harmonious society. With unique advantages, active psychology has been continuously applied in the ideological and political education of colleges and universities, which can effectively improve the efficiency and quality of ideological and political education in colleges and universities.

\section{The Function of Positive Psychology in Ideological and Political Education in Colleges and Universities}

\subsection{Promoting self-regulation and self-assessment of college students}

Positive psychology emphasizes the deep exploration of the potential and ability of college students, which plays an important role in promoting the individual development of college students. In the past ideological and political education work, excessive emphasis on the function of ideological and political education played a less important role in cultivating students' personality and positive qualities, which was detrimental to the exertion of students' subjective initiative. Quality training and emotional experience led to a decline in the quality of ideological and political education [2]. At present, self-adjustment and self-control ability of college students are continuously improving. Through the application of positive psychology, it is helpful for the development of college students' quality and ability, establish correct values and moral qualities, give full play to the subjective initiative of students, actively accept and learn frontier ideas, and truly become ideological and political The main body of education, a sound personality and a sense of self-efficacy have an important role in promoting the effectiveness of ideological and political work in colleges and universities.

\subsection{Excavate and demonstrate the positive quality of college students}

Under the guidance of the theory of positive psychology, it helps to change the perspective of college students, give college students the confidence to explore positive qualities, and constantly improve and improve themselves. As the difference between life and dreams is significant, realizing dreams requires the ability to change reality and mobilize the enthusiasm of college students to change reality [3]. Positive Psychology emphasizes that college students deepen self-knowledge, adjust their level of happiness, view life through a positive eye, and face failures in life. Help students establish correct goals, continue to improve their personalities, and strive towards their goals, and ultimately achieve self-improvement. 


\subsection{Optimize and perfect the organization system of ideological and political education for college students}

The application of positive psychology in the organizational system of ideological and political education in colleges and universities integrates human relations into the social system, which helps promote the harmonious and stable development of the society. Good interpersonal relationships and social relationships play an important role in promoting people's potential and value, forming a powerful ideological and political education force, and further optimizing and improving the ideological and political education organization system for college students. Through the exploration of potential abilities and positive qualities, college students have gradually grown into individualized and intelligent individuals, established harmonious community relations and family relationships, promoted greater sense of responsibility, and effectively improved the effectiveness of ideological and political education in colleges and universities.

\section{The Application of Positive Psychology in Ideological and Political Education in Colleges and Universities}

\subsection{Establish open classrooms and innovate school elective courses}

In the development of ideological and political education in colleges and universities, in order to give full play to the function of positive psychology, Psychology can determine its optimal place of classes and teachers in terms of willpower and successful education, positive psychology, and optimistic and happy life education. Meet the individual needs of college students. Based on this, we select subjects that students are interested in, improve the defects and deficiencies of the traditional teaching model, integrate humanistic care, and respect students' leading consciousness while mobilizing the enthusiasm of students and innovating the teaching model to cultivate complex talents. Through the guidance of positive psychology, to determine the objectives of ideological and political education in universities, and to promote the sublimation of the theory and practice of positive psychology curriculum, to tap the potential and value of college students from a positive perspective, and lay a solid theoretical foundation for the follow-up of efficient ideological and political education. ${ }^{[4]}$.

\subsection{Optimize teaching methods and establish a sound positive psychological theory system}

In order to give full play to the advantages of positive psychology in the work of ideological and political education in colleges and universities, we should further innovate and improve the existing teaching methods, and establish a perfect system of positive psychological theories in light of the actual situation. First of all, in the form of teaching organization innovation, advancing with the times to improve the content of teaching materials; Second, teaching methods to abandon the past spoon-feeding education methods, the implementation of discovery methods, paradigms, and regular organization of positive psychological quality training practical education activities, such as civilized cultivation Engineering, quality development projects, young Marxist training projects and employment and entrepreneurship projects, or arranging psychological drama and psycho dynamic sports games will help enrich educational practice activities, cultivate positive psychological qualities of college students, and achieve curriculum content and teaching methods. Innovation can help improve the effectiveness of ideological and political education in universities [5]. 


\subsection{Strengthen the active education in colleges and universities and conduct psychological therapy on a regular basis}

Through active education in colleges and universities, it helps to introspect and analyze the shortcomings and deficiencies in traditional education. Apart from helping college students correct their own shortcomings and deficiencies, it can also tap into the potential positive qualities and qualities of undergraduates, and aim to cultivate them in practical activities. 6]. In active education, a positive and healthy teaching environment should be created to encourage students to give full play to their subjective initiative, rather than over-controlling them. Otherwise, college students can easily develop resistance. Under the guidance of the theory of positive psychology, to promote the psychological state of college students to reach an ideal stage, is based on the actual situation of different individuals set goals, but not exactly the same. Through active psychological therapy, we can focus on the problems that oppose the past in the application of positive psychology, and devote more energy to strengthening the positive forces of human-to-human relationships. In current active psychological treatment methods, Daoism, Buddhism, and other thoughts are incorporated, and efforts are devoted to solving the positive aspects of troubles and conflicts, deepening self-awareness and understanding, establishing self-trust and safe life patterns, and contributing to enhancing the positive mentality of colleges and universities. Educational effectiveness [7].

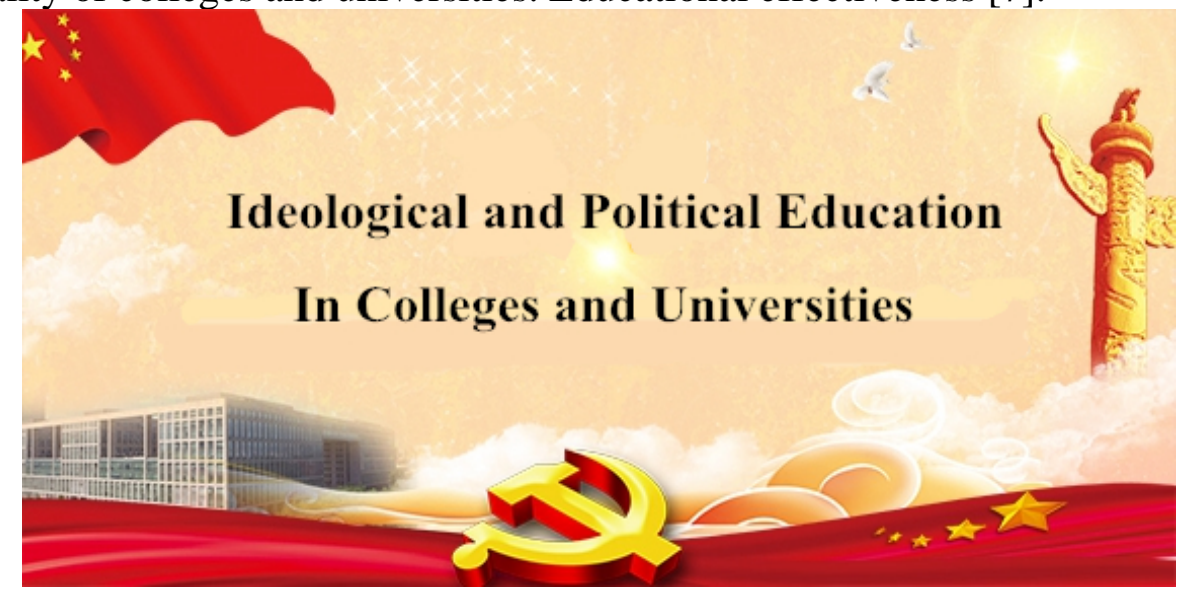

Fig1. The Goal of Ideological and Political Education in Colleges and Universities

\section{Effect of Positive Psychological Theory in Ideological and Political Education in Colleges and Universities}

\subsection{Change the coping style of traditional issues}

The ideological and political education of college students is a means of moral education. There are many educational theories that support the actual work. The traditional education methods mainly focus on instilling compulsory education and promoting the integration of social value and collective value. However, the attention of college students to individual values is not high, and most of them are traditional methods of choice. Positive psychology, on the other hand, stresses that looking at problems from a positive perspective and creating a positive spirit and hope for optimism can help improve the self-efficacy of college students and encourage them to have greater information to solve problems and achieve self-worth. In the process of carrying out ideological and political education in colleges and universities, while addressing the individual values of students, positive emotions and qualities in positive psychology can be absorbed, giving university students a stronger appeal and 
attractiveness, and promoting the pertinence and effectiveness of ideological and political education in colleges and universities. Improving the limitations of the traditional education model and obtaining more substantial teaching results [8].

\subsection{Continuously deepen the content system of ideological and political education in colleges and universities}

The application of positive psychology theory in the work of ideological and political education in colleges and universities is mainly to help college students establish correct values, world outlook and moral values, improve their personality and rich connotations, help cultivate the positive psychological quality and quality of college students, and give college students more meaningful lives. For the follow-up learning and development has an important role in promoting. There is a close connection between ideological and political education and positive psychology education in colleges and universities. The goal is to fully develop the quality and ability of college students, integrate the virtues of positive psychology, and bring deep inspiration and influence to ideological and political education in colleges and universities. For example, in heuristic teaching, integrating the individual development goals and positive needs of college students will help mobilize the enthusiasm of college students, tap their own potential and value, and play an important role in promoting positive emotions and habits for college students. The effectiveness of ideological and political education work has far-reaching significance. Only in this way can we break the limitations of current ideological and political education in universities, broaden the horizon of education, and help improve the effectiveness of ideological and political education in colleges and universities.

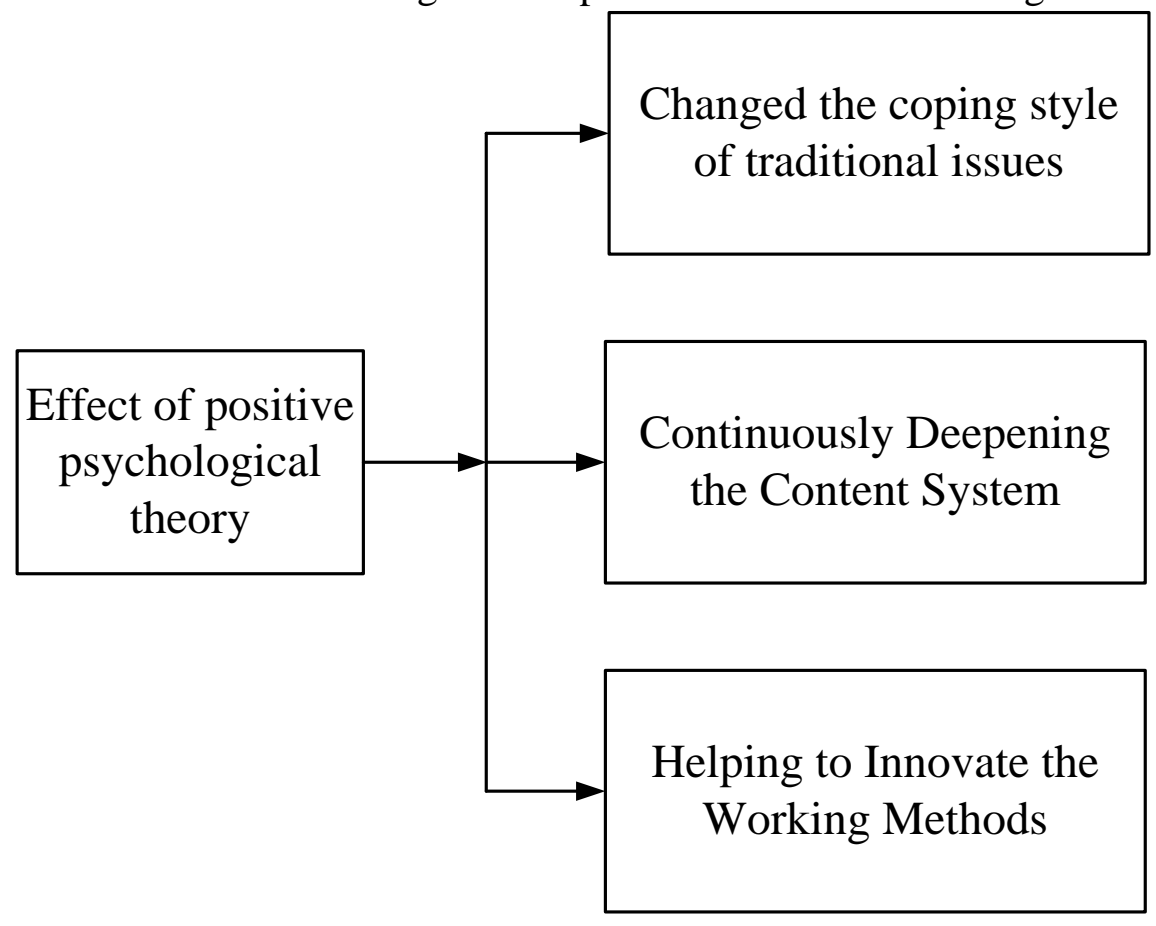

Fig 2. Active Psychology Theory in Ideological and Political Education

\subsection{Innovate the working methods of ideological and political education in colleges and universities}

In the past, the development of ideological and political education in colleges and universities was 
mainly based on propaganda, education, and critical education. The educational methods were too monotonous and did not really give full play to the effectiveness of the original ideological and political education. From the perspective of positive psychology, the implementation of positive education methods such as affirmation, tolerance, and praise can help the college students to develop positive psychology and good quality. In practical education, through active theoretical activities of psychology, college students are actively involved in the process and obtain deep emotional experiences. Students are encouraged to actively publish opinions and establish good qualities of self-esteem, self-improvement, and self-love. For example, in the work of ideological and political education in colleges and universities, through the positive affective experience method in positive psychology, it is helpful to change the limitations of the traditional single theory to instill educational methods, further optimize and innovate methods of ideological and political education in universities, and change the methods of ideological and political education in the past. Inadequacies, effectively improving the effectiveness of ideological and political education in colleges and universities.

\section{Conclusion}

To sum up, applying positive psychology theory in college ideological and political education work, under the guidance of advanced theories, encouraging college students to improve and elevate themselves from a positive perspective, establish correct values and moral qualities, help to tap the potential and value of college students, and create A good education environment helps college students get deep emotional experience and promote the overall development of college students' overall quality.

\section{References}

[1] Ma Hong, et al. The function and realization of positive psychology in ideological and political education in universities. Educational Modernization, Vol. 08 (2017) No. 4, p. 142-143.

[2] Sun Jiandong, et al. The Value and Realization of Positive Psychology in Ideological and Political Education in Colleges and Universities. Journal of Huaihai Institute of Technology (Humanities and Social Sciences), Vol. 14 (2016) No. 07, p. 127-130.

[3] Zhang Qiaoyan, et al. The application of positive psychology in college students' ideological and political education. Modern Business Industry, Vol. 37 (2016) No. 9, p. 148-150.

[4] Wang Qingzheng, et al. The function and application of positive psychology in college students' ideological and political education. Education Review, Vol. 31 (2015) No. 08, p. 105-108.

[5] Ding Huina, et al. Research on the application of positive psychology in post-90 college students' ideological and political education. Wannan Normal University, 2015.

[6] Gao Kui, Liu Kang, et al. Research on the application of positive psychology in ideological and political education in universities. Journal of Xi'an University of Architecture and Technology (Social Science Edition), Vol. 33 (2014) No. 05 , p. 93-96.

[7] Huang Jingru, et al. The Use of Positive Psychology in Improving College Students' Ideological and Political Education. Southwest Petroleum University, 2014.

[8] Lin Yanqing, et al. Research on the Application of Positive Psychology in Ideological and Political Education in Colleges and Universities. Journal of Taiyuan City Vocational and Technical College,Vol. 23 (2013) No. 09, p. 148-150. 